\title{
Investigation of the Strength Properties of Palm Kernel Shell Ash Concrete
}

\author{
Dr. Festus A. Olutoge \\ Dept. of Civil Engineering \\ University of Ibadan, Nigeria \\ fa.olutoge@mail.ui.edu.ng
}

\author{
Habeeb A. Quadri \\ Dept. of Civil Engineering \\ University of Ibadan, Nigeria \\ dejiquadry@yahoo.com
}

\author{
Oladipupo S. Olafusi \\ Dept. of Civil Engineering \\ University of Ibadan, Nigeria \\ olafusidipo@yahoo.com
}

\begin{abstract}
Many researchers have studied the use of agro-waste ashes as constituents in concrete. These agro-waste ashes are siliceous or aluminosiliceous materials that, in finely divided form and in the presence of moisture, chemically react with the calcium hydroxide released by the hydration of Portland cement to form calcium silicate hydrate and other cementitious compounds. Palm kernel shell ash (PKSA) is a by-product in palm oil mills. This ash has pozzolanic properties that enables it as a partial replacement for cement but also plays an important role in the strength and durability of concrete. The use of palm kernel shell ash (PKSA) as a partial replacement for cement in concrete is investigated. The objective of this paper is to alleviate the increasing challenges of scarcity and high cost of construction materials used by the construction industry in Nigeria and Africa in general, by reducing the volume of cement usage in concrete works. Collected PKSA was dried and sieved through a $45 \mathrm{um}$ sieve. The fineness of the PKSA was checked by sieving through 45um sieve. The chemical properties of the ash are examined whereas physical and mechanical properties of varying percentage of PKSA cement concrete and $100 \%$ cement concrete of mix 1:2:4 and 0.5 water-cement ratios are examined and compared. A total of 72 concrete cubes of size $150 \times 150 \times 150$ $\mathbf{m m}^{3}$ with different volume percentages of PKSA to Portland cement in the order $0: 100,10: 90$ and $30: 70$ and mix ratio of $1: 2: 4$ were cast and their physical and mechanical properties were tested at 7, 14, 21 and 28 days time. Although the compressive strength of PKSA concrete did not exceed that of OPC, compressive strength tests showed that $10 \%$ of the PKSA in replacement for cement was $22.8 \mathrm{~N} / \mathrm{mm}^{2}$ at 28 days; which was quite satisfactory with no compromise in compressive strength requirements for concrete mix ratios 1:2:4. This research showed that the use of PKSA as a partial replacement for cement in concrete, at lower volume of replacement, will enhance the reduction of cement usage in concretes, thereby reducing the production cost. This research was carried out at the University of Ibadan, Ibadan, Nigeria.
\end{abstract}

Keywords: Agro-wastes; concrete; ordinary Portland cement; palm kernel shell ash (PKSA); compressive strength

\section{NOTATIONS}

The following abbreviations are used in this paper:

ASTM American Society for Testing and Materials

OPC Ordinary Portland Cement

PKSA Palm Kernel Shell Ash

\section{INTRODUCTION}

Concrete is the most versatile heterogeneous construction material and the impetus of infrastructural development of any nation [1]. Concrete is a composite inert material comprising of a binder course (e.g. cement), mineral filler (body) or aggregates and water [2]. Concrete is one of the oldest manufactured construction materials used in construction of various structures around the world. The cost of concrete and other construction materials in Nigeria is currently so high that the majority of individuals find it difficult to afford, with the exception of Government, Industrial and Business Corporations. There had been calls from several government quarters on means to reduce the cost of Civil Engineering construction works by adopting cheap locally available engineering materials. The Nigerian Building and Road Research Institute (NBRRI) was established in order to fulfill this mandate.

Ordinary Portland cement (OPC) is acknowledged as the major construction material throughout the world. The production rate is approximately 2.1 billion tonnes per year, and is expected to grow exponentially to about 3.5 billion tonnes per year by 2015 [3]. According to Adepegba [4] the annual cement requirement in Nigeria is about 8.2 million tonnes and only 4.6 million tonnes of Portland cement are produced locally. The balance of 3.6 million tonnes or more is imported. If alternative cheap cement can be produced locally the demand for Portland cement will reduce and ultimately reduce the cost. The search for suitable local materials to manufacture pozzolana cement was therefore intensified and one of the discoveries was that of palm bunch wastes [4].

Most of the increase in cement demand will be met by the use of supplementary cementing materials, in order to reduce the green gas emission [5]. Industrial wastes, such as blast furnace slag, fly ash and silica fume are being used as supplementary cement replacement materials and, recently, agricultural waste are also being used as pozzolanic materials in concretes, such as Palm Oil Fuel Ash (POFA), silica from rice husk and rice husk ash [6]. When pozzolanic materials are incorporated to concrete, the silica present in these materials reacts with the $\mathrm{Ca}(\mathrm{OH})_{2}$ released during the hydration of cement and forms additional calcium silicate hydrate (C-S-H), 
which improves durability and the mechanical properties of concrete [7].

PKSA has the potential to be used as a construction material. It is a by-product in palm oil mills. After palm oil is extracted from the palm oil fruit, both palm oil husk and palm oil shell are burned as fuel in the boiler of palm oil mill. Generally, after combustion; about 5\% PKSA by weight of solid wastes is produced [8]. The ash produced sometimes varies in tone of color from whitish grey to darker shade based on the carbon content in it. In other words, the physical characteristic of PKSA is very much influenced by the operating system in the palm oil factory. Utilization of PKSA is minimal and unmanageable while its quantity increases annually and most of the PKSA are disposed as waste in landfills causing environmental problems [9]. To solve the energy problems, solid wastes from palm oil residue are used as fuel to produce steam for electricity generation. After burning, an ash by-product is produced. As a solution to the disposal problem of the ash derived from palm oil, research studies have been carried out to examine the feasibility of using the ash as cement replacement materials [10]. The objective of this paper is to study the potential of PKSA as partial replacement for cement in concrete, the effects of increasing the volume of PKSA replacements on the compressive strength of concrete and the extent to which the PKSA can partially replace cement in concrete.

\section{TEST DETAILS}

\section{A. Specimen Preparation}

PKSA used in this study was collected from a local palm oil processing factory at Abedo village via Moniya in Akinyele Local Government Area of Ibadan, Oyo State. Already dried palm kernel shell was collected. It was burnt and grinded into fine ash particles (PKSA). The PKSA was sieved through 45um sieve in order to remove any foreign material and bigger size ash particles; and only the fine ashes which pass through 45um sieve were collected (which is available abundantly locally). The chemical analysis of the PKSA samples was further carried out in a chemistry laboratory to examine its chemical constituent. The fine aggregate used was sharp sand. Granite was used as coarse aggregate.

\section{B. Mix proportions of concrete specimens}

The proportioning by weight was used in this research. The cement-aggregates ratio used in this work was 1:2:4. PKSA were used to replace OPC at dosage levels of $10 \%$ and $30 \%$ replacement by weight of binder. The mix proportions used were as calculated below:

\section{No. of Cubes per Batch $=24$}

(i.e. six cubes each for ages 7, 14, 21 and 28 days tests)

Note: Batch implies Control Mix (0\% PKSA Replacement), $10 \%$ PKSA Replacement and 30\% PKSA Replacement

$$
\begin{gathered}
\text { Size of each Cube }=150 \mathrm{~mm} \times 150 \mathrm{~mm} \times 150 \mathrm{~mm} \\
\text { Vol. of Cube }=150^{3}=3.375 \times 10^{-3} \mathrm{~m}^{3}
\end{gathered}
$$

$$
\text { Vol. of } 24 \text { Cubes }=24 \times 3.375 \times 10^{-3}=0.081 \mathrm{~m}^{3}
$$

To cater for wastage, it was factored by 1.2

$$
\text { Vol. of the Batch }=0.081 \times 1.2=0.0972 \mathrm{~m}^{3}
$$

The ratio used in this research is 1:2:4= cement: Sand: Coarse Aggregate

$$
\begin{gathered}
\text { Cement }=1 / 7 \\
\text { Vol of Cement needed }=(1 / 7) \times 0.0972 \mathrm{~m}^{3}=0.0138858 \mathrm{~m}^{3} \\
\text { Standard Weight of Concrete }=2400 \mathrm{~kg} / \mathrm{m}^{3}
\end{gathered}
$$

Therefore:

$$
\begin{gathered}
\text { Weight of Cement in one Batch }=2400 \times 0.0138858 \\
=33.33 \mathrm{~kg} \cong 34 \mathrm{~kg}
\end{gathered}
$$$$
\text { Vol. of Sand }=(2 / 7) \times 0.0972 \mathrm{~m}^{3}=0.027774 \mathrm{~m}^{3}
$$

Weight of Sand $=2400 \times 0.0277714=66.65 \mathrm{~kg} \cong 67 \mathrm{~kg}$

Vol. of Coarse Aggregate $=(4 / 7) \times 0.0972 \mathrm{~m}^{3}=0.0555429 \mathrm{~m}^{3}$

Weight of Coarse Aggregate $=2400 \times 0.0555429=133.30 \mathrm{~kg}$

$$
\cong 134 \mathrm{~kg}
$$

The water to binder ratio adopted in the course of this research was 0.5 and this was used to calculate the amount or weight of water required per batch.

$$
\begin{aligned}
& \text { Weight of water }=0.5 \times \text { weight of binder (Cement) } \\
& =0.5 \times 34 \mathrm{~kg}=17 \mathrm{~kg}
\end{aligned}
$$

Based on the calculations above, the Mix Design of Concrete in Table I below was generated.

TABLE I. MIX DESIGN OF CONCRETE

\begin{tabular}{|c|c|c|c|}
\hline $\begin{array}{c}\text { Constituent } \\
\text { Materials }\end{array}$ & $\begin{array}{c}\text { Control } \\
\mathbf{0 \%}\end{array}$ & $\begin{array}{c}\text { PKSA } \\
\mathbf{1 0} \%\end{array}$ & $\begin{array}{c}\text { PKSA } \\
\mathbf{3 0} \%\end{array}$ \\
\hline Cement (kg) & 34.0 & 30.6 & 23.8 \\
\hline PKSA (kg) & 0.0 & 3.4 & 10.2 \\
\hline $\begin{array}{c}\text { Fine Aggregate } \\
\text { (kg) }\end{array}$ & 67.0 & 67.0 & 67.0 \\
\hline $\begin{array}{c}\text { Coarse } \\
\text { Aggregates (kg) }\end{array}$ & 134.0 & 134.0 & 134.0 \\
\hline $\begin{array}{c}\text { Water/binder } \\
\text { ratio }\end{array}$ & 0.5 & 0.5 & 0.5 \\
\hline Total water (kg) & 17.0 & 17.0 & 17.0 \\
\hline
\end{tabular}

III. TEST PROCEDURE

Twenty Four (24) cubes each were cast for OPC as a control mix, OPC replaced with $10 \%$ and $30 \%$ of PKSA $45 \mathrm{um}$, making a total of Seventy Two (72) cubes. All freshly cast specimens were left in the moulds for 24 hours before being demoulded and then cured in water until it was time to be tested as shown in Figures 1 and 2. Since the numbers of molds required were many, wooden moulds of size $150 \times 150 \times 150 \mathrm{~mm}$ were made to cast the entire specimen in one day. The weights of the cubes were examined prior to crushing so as to 
determine their densities as shown in Figure 3. Compressive test was conducted at ages of 7, 14, 21, 28 days as shown in Figure 4.

\section{RESULTS AND DISCUSSION}

Figure 1 shows the PKSA concrete cubes while setting, Figure 2 shows the curing process of the cubes, Figure 3 shows the weighing process to determine the density of the cubes while Figure 4 shows the compressive strength testing process. Table II shows the details of the chemical properties of the PKSA; Table III shows the detailed densities of the concrete samples, while Table IV shows the results of the compressive strength test.

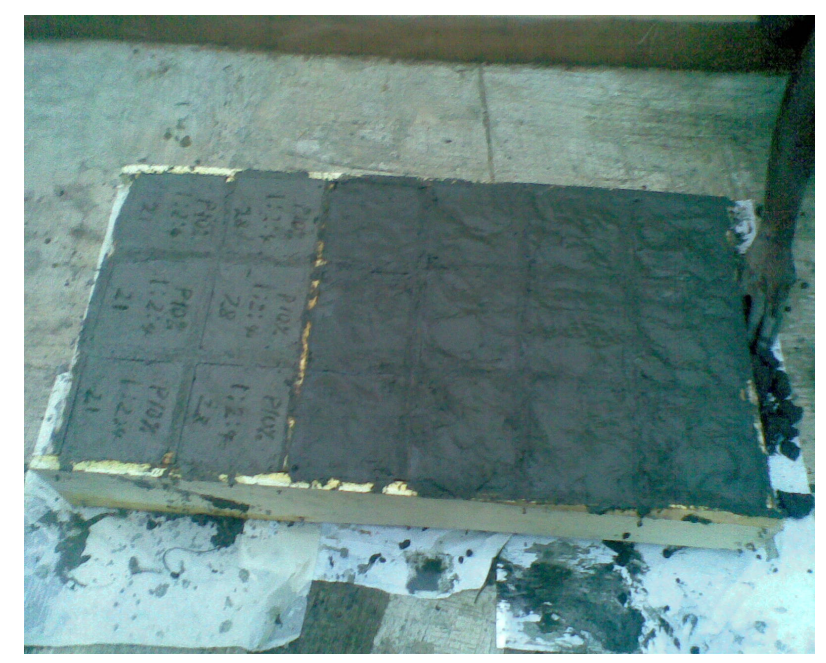

Fig. 1. PKSA Concretes while setting

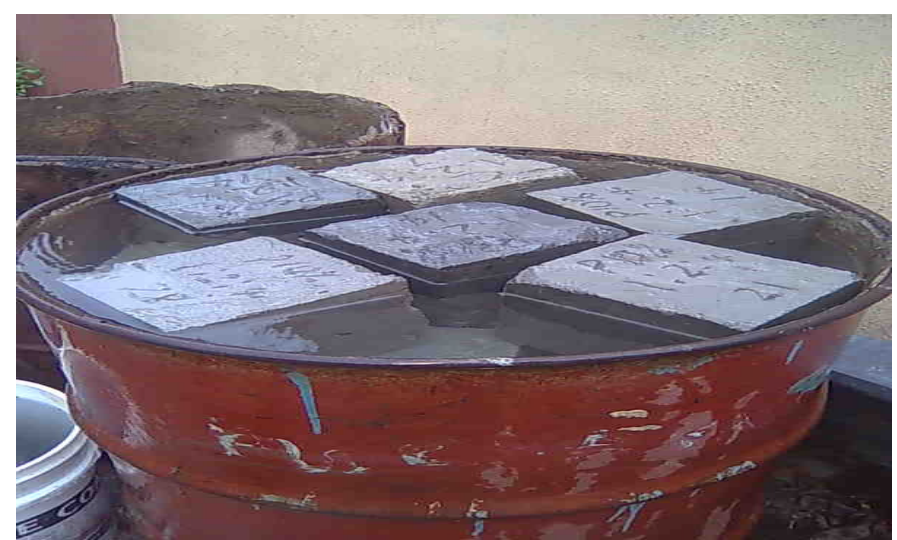

Fig. 2. PKSA Concretes in a Curing Basin

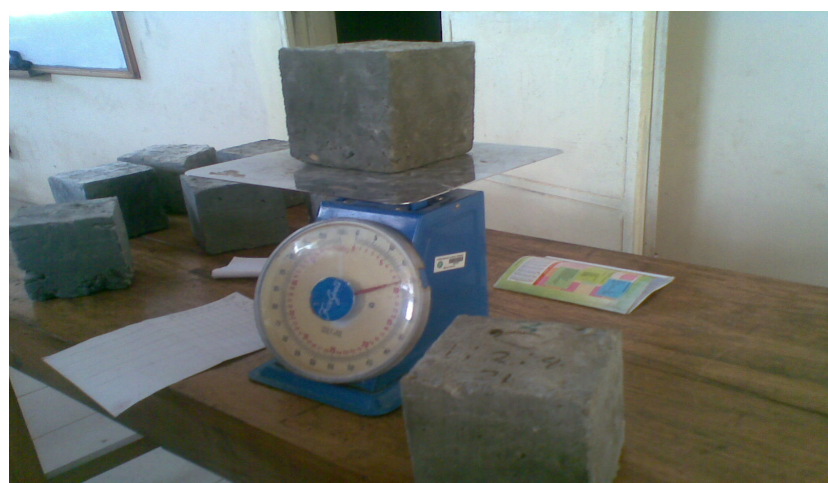

Fig. 3. Weighing process to determine densities of concrete samples

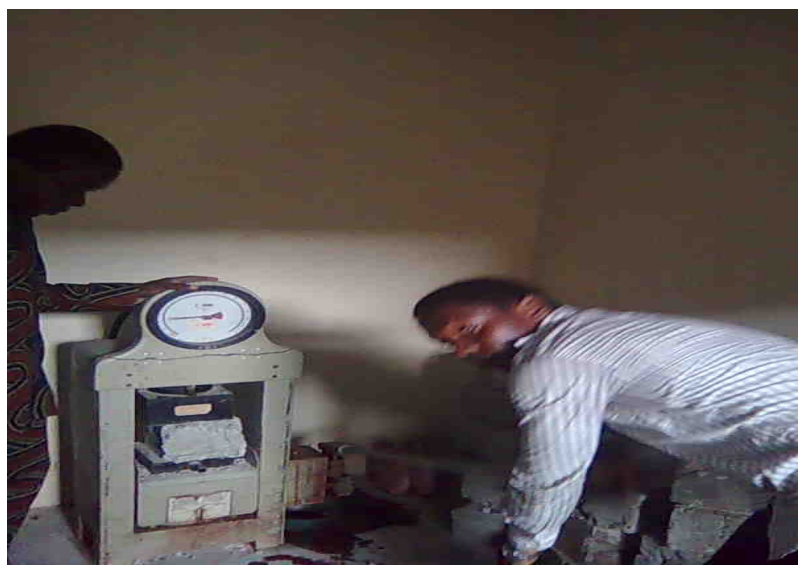

Fig. 4. Compressive Strength Test

TABLE II. PARTICLE SIEVE ANALYSIS OF PKSA

\begin{tabular}{|c|c|}
\hline Sieve Size (mm) & \% Passing \\
\hline 0.600 & 100 \\
\hline 0.425 & 99.9 \\
\hline 0.300 & 97.5 \\
\hline 0.212 & 83.3 \\
\hline 0.150 & 49.8 \\
\hline 0.075 & 33.5 \\
\hline 0.045 & 31.3 \\
\hline
\end{tabular}

TABLE III. SPECIFIC GRAVITY OF PKSA

\begin{tabular}{|c|c|c|}
\hline Sample Weight (g) & Test A (g) & Test B (g) \\
\hline W1 & 28.20 & 31.70 \\
W2 & 51.30 & 55.90 \\
W3 & 97.90 & 103.10 \\
W4 & 85.40 & 88.90 \\
\hline GS & 2.18 & 2.41 \\
\hline
\end{tabular}

$$
\begin{aligned}
& G S=W_{2}-W_{1} /\{(W 4-W 1)-(W 3-W 2)\} \\
& \text { Average } G S=\frac{2.18+2.41}{2}
\end{aligned}
$$

$$
G S=2.295 \cong 2.30
$$


TABLE IV. CHEMICAL PROPERTIES OF PKSA

\begin{tabular}{|c|c|c|}
\hline Chemical Composition (\%) & OPC & PKSA \\
\hline SiO2 & 22.13 & 54.810 \\
\hline $\mathbf{A l 2 O 3}$ & 3.74 & 11.4 \\
\hline Fe2O3 & 2.97 & 0.362 \\
\hline CaO & 63.36 & 8.786 \\
\hline MgO & 2.58 & 6.108 \\
\hline K2O & 0.52 & 6.254 \\
\hline True Density (g/cm3) & 2.97 & 2.60 \\
\hline
\end{tabular}

TABLE V. DENSITY OF THE CUBES

\begin{tabular}{|c|c|c|c|c|}
\hline$\left(\times \mathbf{1 0}^{3} \mathbf{~ k g} / \mathbf{m}^{3}\right)$ & 7 days & 14 days & 21 days & 28 days \\
\hline $\begin{array}{c}\mathbf{0 \%} \text { PKSA } \\
\text { Content } \\
(\text { Control) }\end{array}$ & 2.53 & 2.57 & 2.62 & 2.64 \\
\hline $\begin{array}{c}\mathbf{1 0 \%} \text { PKSA } \\
\text { Content }\end{array}$ & 2.44 & 2.52 & 2.55 & 2.59 \\
\hline $\begin{array}{c}\mathbf{3 0 \%} \text { PKSA } \\
\text { Content }\end{array}$ & 2.46 & 2.47 & 2.49 & 2.52 \\
\hline
\end{tabular}

TABLE VI. CHARACTERISTIC STRENGTH OF THE CUBES

\begin{tabular}{|c|c|c|c|c|}
\hline (N/mm $)$ & 7 days & 14days & 21days & 28days \\
\hline $\begin{array}{c}\text { 0\% PKSA } \\
\text { Content } \\
\text { (Control) }\end{array}$ & 14.59 & 18.08 & 21.11 & 26.80 \\
\hline $\begin{array}{c}\mathbf{1 0 \%} \text { PKSA } \\
\text { Content }\end{array}$ & 11.41 & 16.22 & 17.33 & 22.80 \\
\hline $\begin{array}{c}\text { 30\% PKSA } \\
\text { Content }\end{array}$ & 8.76 & 13.00 & 15.40 & 18.44 \\
\hline
\end{tabular}

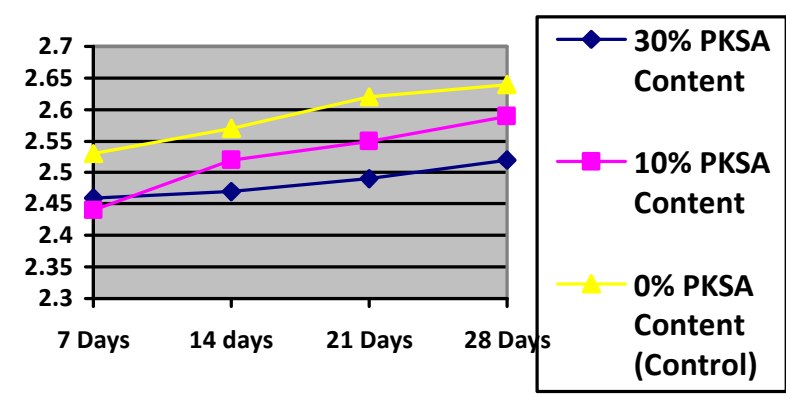

Fig. 5. Densities $\left(\times 10^{3} \mathrm{~kg} / \mathrm{m}^{3}\right)$ of various PKSA contents

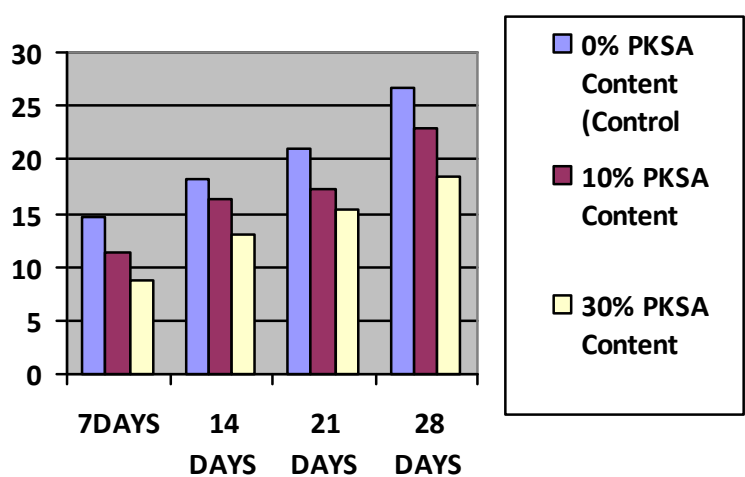

Fig. 6. Compressive strengths of various PKSA contents

\section{SAMPLE PROPERTIES}

The PKSA collected were grayish in color. The main constituents of the PKSA are Silicon (as $\mathrm{SiO}_{2}$ ), Aluminum (as $\mathrm{Al}_{2} \mathrm{O}_{3}$ ), and Iron Oxide (as $\mathrm{Fe}_{2} \mathrm{O}_{3}$ ). The total amount of $\mathrm{SiO}_{2}$, $\mathrm{Al}_{2} \mathrm{O}_{3}$ and $\mathrm{Fe}_{2} \mathrm{O}_{3}$ present in PKSA is $66.572 \%$ which is more than the minimum required (50\% Min.) specified by [11], for Type C Ash; while its Calcium oxide $(\mathrm{CaO})$ content is about $8.786 \%$; as shown in Table II. The specific gravity of the PKSA was gotten to be 2.30 ; which was less than that of the OPC of 3.15. This means a considerable greater volume of cementitious materials will result from mass replacement for cement.

Water absorption, initial and final setting time of the PKSA concrete took longer time than OPC concrete, which implies that the presence of PKSA increases the water absorption and setting time of concrete. Therefore the higher the PKSA content in concrete, the longer the water absorption and setting time. This is so because, the factors that influence setting time of concretes are the volume of Portland cement, water requirement, temperature of the concrete and the reactivity of the pozzolan. However, PKSA concretes do not absorb water as fast as OPC concretes; thereby retarding hydration processes in the PKSA concrete (PKSA concretes retain water for a longer period before it starts to dry up slowly).

Table III revealed that the density decreased with increasing percentage of PKSA and increased with curing age (i.e. the more the ash content in the concrete, the lower the density and the density also increases with curing age). This is because density is a reflection of weight; as concretes gain strength and weight with curing age due to hydration process; so PKSA concretes are lighter than OPC concretes due to its slow strength and weight development and the volume of Portland cement in the concretes determines the porosity and the degree of compaction of the concrete.

Table IV revealed that $10 \%$ PKSA Concrete at 28 days was $22.80 \mathrm{~N} / \mathrm{mm}^{2}$ meets the minimum required strength of concrete at 28 days; while the slow development of strength which is an important characteristic of pozzolans could be responsible for the 28 days strength of $30 \%$ PKSA concrete which was 18.44 $\mathrm{N} / \mathrm{mm}^{2}$. The rate of strength development also depends on the volume of cement replacement. However, they tend to gain more strength over a longer period of time beyond 28 days because concretes made with pozzolans are generally stronger, harder and more durable. This research was limited to a $28^{\text {th }}$ day examination. It is recommended that subsequent research should examine 90days strength tests and/or use concrete accelerators which increase hydration processes thereby influencing strength at 28days.

\section{CONCLUSION}

Based on the findings from this study, the following conclusions can be arrived at;

1. PKSA contains all the main chemical constituents of cement though in varying quantities compared to that 
of OPC; this means it will be a good replacement if the right percentage is used.

2. The use of PKSA as a partial replacement for cement exhibits a lower water absorption rate and slower setting time of concrete.

3. Concrete strengths increases with curing age and decreases with increasing percentage of PKSA replacement in concrete.

4. The use of PKSA will reduce the volume of cement used in concrete, thereby reducing the cost of concrete production.

5. The use of PKSA will minimize the environmental issues arising from the disposal of Palm kernel wastes.

\section{RECOMMENDATION}

1. Subsequent studies on concretes with the replacement of cement with PKSA should be allowed to cure for 90 days, by which pozzolanic activity of ash is believed to have been concluded.

2. Reduced cost of construction arising from the use of locally available agricultural waste materials such as PKSA will enhance infrastructural developments.

\section{REFERENCES}

[1] O. S. Olafusi, F. A. Olutoge, "Strength properties of corn cob ash concrete", Journal of Emerging Trends in Engineering and Applied Sciences, Vol. 3, No. 2, pp. 297-301, 2012

[2] V. O. Oyenuga, Simplified reinforced concrete design, ASTROS Limited, Lagos, Nigeria, 2001

[3] S. J. Coutinho, "The combined benefits of CPF and RHA in improving the durability of concrete structures. Cement and Concrete Composites", Cement and Concrete Composites, Vol. 25, No. 1, pp. 51-59, 2003

[4] D. Adepegba, "Pozzolanic activity of palm bunch wastes" Materials and Structures/Materiaux et Constructions, Vol. 22, pp. 220-224, 1989

[5] A. Bentur, "Cementitious materials - nine millennia and a new century: past, present, and future", Journal of Materials in Civil Engineering, Vol. 14, No. 1, pp. 2-22, 2002

[6] G. R. de Sensale, "Strength development of concrete with rice-husk ash", Cement and Concrete Composites, Vol. 28, No. 2, pp. 158-160, 2006

[7] S. Igarashi, A. Watanabe, M. Kawamura, "Evaluation of capillary pore size characteristics in high-strength concrete at early ages", Cement and Concrete Research, Vol. 35, No. 3, pp. 513-519, 2005

[8] K. M. Abdullah, W. Hussin, F. Zakaria, R. Muhamad, Z. Abdul Hamid, "POFA: a potential partial cement replacement material in aerated concrete" Proceedings of the 6th Asia-Pacific Structural Engineering and Construction Conference (APSEC 2006), Kuala Lumpur, Malaysia, 5-6 September, 2006

[9] W. Tanqchirapat, T. Saeting, C. Jaturapitakkul, K. Kiattikomol, A. Siripanichgorn, "Use of waste ash from palm oil industry in concrete", Waste Management, Vol. 27, No. 1, pp. 81-88, 2007.

[10] J. -H. Tay, K. -Y. Show, "Use of ash derived from oil-palm waste incineration as a cement replacement material", Journal of Resources, Conservation and Recycling, Vol.13, No. 1, pp. 27-36, 1995

[11] ASTM Designation: C 618 standard specification for fly ash and raw or calcined natural pozzolan for use as mineral admixture in Portland cement concrete, Annual Book of ASTM Standards, American Society for Testing and Materials, 1994 